\title{
REDAÇÃO DA FUVEST: O VISUAL E O VERBAL
}

\section{As imagens povoam o cotidiano das pessoas e, no entanto, permanecem como sistemas de signos desconhecidos}

Acabo de ler o artigo ${ }^{1}$ de Caio Túlio Costa Adorno neles na revista da Folha de 22.01 .95 e me entusiasmei. Pensava que era a única pessoa de São Paulo a ter gostado da prova de redação da FUVEST à qual ele se refere.

Deparei-me com a prova por acaso, quando me desfazia dos jornais acumulados em casa nos meus três meses de ausência do Brasil. Pensei que pela primeira vez o tema para redação se confrontava com o desafio epistemológico da contemporaneidade: a relação entre o pensamento visual e o pensamento verbal.

Lembrei-me do meu vestibular e do tema parnasiano que me foi dado para redação: "A casa paterna". Não teria que reclamar pois tive a maior nota de redação daquele vestibular porque à proposta sentimental respondi com sentimentalismo exarcebado, pois desconhecia os encantos da "casa paterna" por ter perdido meu pai aos três anos de idade. Mas, saí da prova lamentando com outros companheiros termos perdido a oportunidade de escrever sobre fatos atuais e problemas sóciopolíticos que nos cercavam. Nosso desejo estava se antecipando à temática de redação para vestibular que dominou nos anos 70 . Se formos estudar a história dos temas de redação para vestibular, certamente vamos descobrir, com raras exceções, que as propostas estiveram sempre atrasadas em relação aos estilos literários e à história do pensamento. Este ano não.
A proposta de leitura da obra de Andy Warhol $^{2}$, conjuntamente com a leitura dos textos de Adorno ${ }^{3}$ que os vestibulandos de 95 tiveram de enfrentar, é "um tema inteligente que premia a reflexão" não só para a leitura da linguagem verbal mas também para a leitura da imagem.

A leitura da imagem é prioritária no mundo atual. Um epistemólogo alemão que foi meu companheiro de residência no Bellagio Study and Conference Center da Rockefeller Foundation na Itália me dizia em conversa particular (daí não ser ético citar seu nome) que dois campos de conhecimento, a imagem e a ecologia, requerem uma nova epistemologia, revolucionando concepções já assentadas.

Razões de ordem prática também conferem importância à leitura da imagem.

Há uma pesquisa na França mostrando que $82 \%$ de nossa aprendizagem informal se dá através da imagem e $51 \%$ desta aprendizagem é inconsciente. A imagem nos domina porque não conhecemos a gramática visual nem exercitamos o pensamento
A AUTORA
Ana Mae Barbosa
Professora Doutora do Departamento de Artes Plâsticas da ECA-USP.

1. COSTA, Caio Túlio. "Adorno Neles" em Posfácio. Revista da Folha. Ano 3, n.144, 22 de janeiro de 1995 , p.62.

2. Andy Warhol: artista plástico norte-americano, precursor, nos anos 60, da pop art. A prova da FUVEST propõe aos candidatos redação a partir de um quadro de Warhol que reproduz diversas vezes o rosto da atriz Marylin Monroe e textos de Theodor W. Adorno. (N.E.)

3. Theodor Wiesengrud Adorno (I903-1969): filósofo, estudioso dos processos de comunicação, reorganizou em 1950 o Instituto de Pesquisa Social de Frankfurt fundado em 1923 (Escola de Frankfurt). Na obra Dialética do huminismo (1947) Adorno e Max Horkheimer cunharam a expressão "indústria cultural”. Escreveu dentre outros: Estudos sobre Husserl e os antinômios fenomenológicos (1956); Dialética negativa (1966) e Teoria estética (1968).

Adorno, Horkheimer e Walter Benjamim foram os principais teóricos da Escola de Frankfurt, cujo conjunto de concepções ficou conhecido pela expressäo "Teoria Crítica". (N.E.) 
visual para descobrir sistemas de significação através das imagens.

Uma alfabetização para a leitura da imagem através da educação formal tornaria consciente toda aprendizagem, alimentando a capacidade de reflexão do estudante.

\section{LEITURA DA IMAGEM}

Os estudantes reclamam porque nunca ouviram falar de Andy Warhol. Agora já ouviram e portanto deram um passo em direçâo à alfabetizalção cultural. Aproveitem e dêem uma passada no MAM (Museu de Arte Moderna) do lbirapuera que possui uma obra de Andy Warbol graças à doaçāo de Michael Makenzic .

Os professores tradicionalmente, no Brasil, têm medo da imagem na sala de aula. Da televisão às artes plásticas, a sedução da imagem os assusta, porque não toram preparados para decodificá-la e usá-lá em prol da aprendizagem reflexiva de seus alunos.

Revendo meu material de pesquisa sobre a historia do ensino da arte encontro uma outra polêmica sobre imagem no vestibular, datada de fevereiro de 1928. Trata-se da gritaria generalizada contra a introdução do desenho nos vestibulares para a então prestigiosa Escola Normal do Rio de Jumeiro. Foi no tempo de Femando de Azevedo (professor de nosiso atual presidente) como diretor da Instrução Pública do Distriro Federal.

As alunas para entrarem na Escola Normal faziam prova de Português, Aritmética, Geografía e História do Brasil. A equipe de Fernando de Azevedo acrescentou exames de geometria e desenho (livre) para o vestibular de 1928 .

A geometria foi facilmente aceita, como o fez um jornalista do Jornal do Brasil (10.02.28) que disse "unir a prova de geometria à de aritmélica pode de certo modo pacecer favorável às candidatas". Já a inclusão do desenho foi "mathada" por

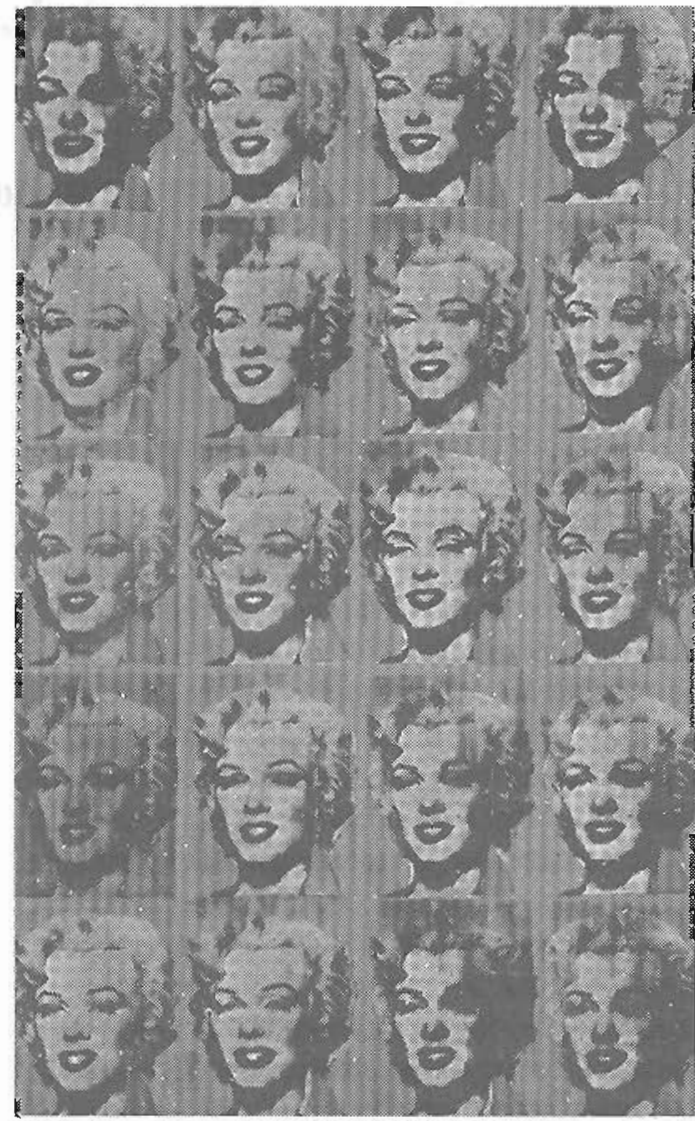

Andy Warhols, tela de 1962. Marilyn Monroc Diptich. $82 \times 114$ " Coleção Burton Tremaine, Meriden, Connecticut.

todos os jornais da época. O Imparcial, $\mathbf{O}$ Jornal, A Pátria, O País, Jornal do Comércio, O Globo, Correio da Manhã chamavam a prova de desenho de extravagante acréscimo "que ameaçava as candidatas à Escola Normal". Mas, o Gabinete do Diretor da instrução Pública reagiu e respondeu em rodos os jornais no mesmo diapasão agressivo dizendo: "Desconhecer a necessidade do desenho é cristalizar umá pedagogia de 30 anos atrás". Ouso parafrasear esia alirmação dizendo: "Desconhecer a necessidade de alfabetização visual através da leitura da imagem é cristalizar uma pedagogia de 30 anos atrás".

4. Ardista plástico, crílico de arte E curador independente em Nová York. (NE.)

5 Reproduçāo de COPLANS, John. Andy Warhol. Londres: Weidenfeld e Nicolson [s.d.]. p.70. 